\title{
Utilization and uncertainties of satellite precipitation data in flash flood hydrological analysis in ungauged watersheds
}

\author{
Sapountzis M. ${ }^{1}$, Kastridis A. ${ }^{1 *}$, Kazamias A.-P. ${ }^{1}$, Karagiannidis A. ${ }^{2}$, Nikopoulos P. ${ }^{1}$ and Lagouvardos K. ${ }^{2}$ \\ ${ }^{1}$ Department of Forest and Water Engineering, Faculty of Forestry and Natural Environment, Aristotle University of Thessaloniki, 54124 \\ Thessaloniki, Greece \\ ${ }^{2}$ Institute of Environmental Research and Sustainable Development, National Observatory of Athens, Lofos Koufou, 15236 Athens, \\ Greece \\ Received: 11/08/2021, Accepted: 26/09/2021, Available online: 04/10/2021 \\ *to whom all correspondence should be addressed: e-mail: akastrid@for.auth.gr \\ https://doi.org/10.30955/gnj.003905
}

\section{Graphical abstract}

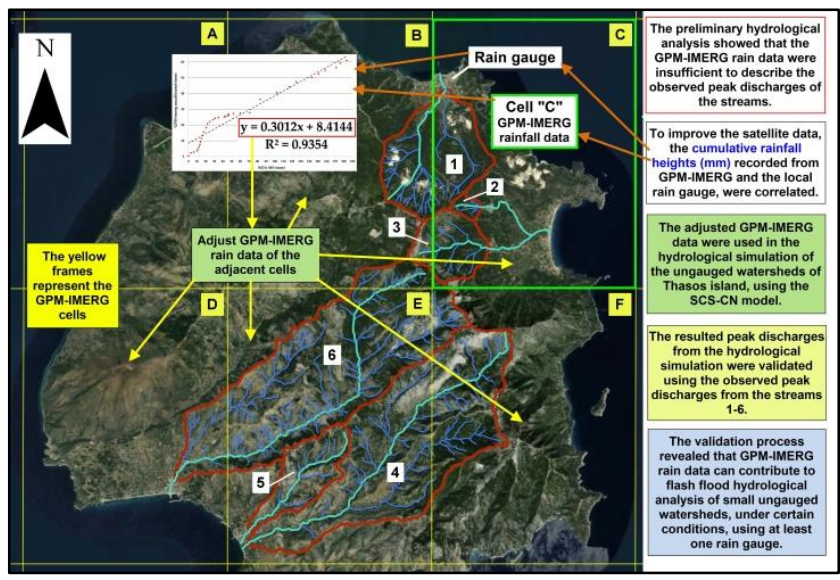

Abstract

Aim of the study is to examine the potential utilization of satellite precipitation data to estimate the peak discharges of flash floods in ungauged Mediterranean watersheds. Cumulative precipitation heights from local rain gauge and the GPM-IMERG were correlated in a scatter plot. The calculated linear equations were used to adjust the uncalibrated GPM-IMERG precipitation data in Thasos island (Northern Greece), to investigate the mechanisms of the flash floods recorded in November 2019 and to evaluate the significance of satellite precipitation data in hydrological modeling. The uncalibrated GPM-IMERG precipitation failed to explain the flash floods phenomena. The rain gauge data are reliable to accurately predict the peak discharges only in cases, where the rain gauges are within the study area. The strong correlation between ground rainfall data and satellite spatiotemporal precipitation data $\left(R^{2}>0.65\right)$, provides linear regression equations that, through their extrapolation and appliance to the rest of the flooded area, could adjust and correct the satellite data, optimizing the efficiency and accuracy of flash flood analysis, especially in ungauged watersheds. The proposed methodology could highly contribute to the optimization of flood mitigation measures establishment, flood risk assessment, hydrological and hydraulic simulation of flash flood events in ungauged watersheds.

Keywords: Ephemeral streams, flash flood, GPM-IMERG, high water marks, hydrological modeling, Mediterranean watersheds, SCS-CN model.

\section{Introduction}

Flash flood phenomena are among the most disastrous natural hazards and so far, have caused considerable human fatalities (Diakakis et al., 2019; Faccini et al., 2015), significant financial loses and other noteworthy impacts related to socioeconomic activities (Boithias et al., 2017; Hooke, 2016). Flash floods are very often caused by high intensity rainfall events within small mountainous catchments, which present fast-response time (Kastridis and Stathis, 2020; Sapountzis and Stathis, 2014). Several factors/parameters influence the development and the severity of flash floods, such as the hydrometeorological conditions, topography, and geomorphology of the catchment and human interventions (Kastridis and Stathis, 2015; Kotroni et al., 2005). Precipitation constitutes the most crucial factor, since the intense rainfall events occur at the same space-time in the catchment with the flash flood evolution (Kelsch et al., 2001). In Mediterranean countries, flash floods are considered to be the most dangerous, frequent and catastrophic natural phenomena (Diakakis et al., 2019; Gaume et al., 2016; Lagouvardos et al., 2020).

The comprehension of the hydrological processes of flash floods by quantifying the response of heavy rainfall events is necessary for flood forecasting and development of mitigation measures. Unfortunately, most mountainous catchments form numerous of ephemeral streams, are often ungauged or poorly gauged, a fact that creates great uncertainty in flash flood modelling (Borga et al., 2010). In parallel, for most of the flash flood events, there are not discharge measurements and the precipitation measurements are either missing, or not adequate to fully describe the spatiotemporal variability of precipitation (Marchi et al., 2010). 
Accurate ground precipitation data in space-time constitute input of great importance for running a hydrological model (Soo et al., 2020). An alternative method of obtaining these data is through remote sensing. Satellite remote sensing can provide precipitation estimates at high space-time variability, which can be extremely useful in ungauged catchments or areas of poor rain gauge networks (Behrangi et al., 2011). Nowadays, many operational Satellite Precipitation Products (SPPs) are available with quasi-global coverage, at sub-daily temporal resolution. Among these products, there is the Climate Prediction Center MORPHing technique (CMORPH) analysis (Joyce et al., 2004), the Tropical Rainfall Measurement Mission (TRMM), Multi-satellite Precipitation Analysis (TMPA) (Huffman et al., 2007), the Precipitation Estimation from Remotely Sensed Information using Artificial Neural Networks-Cloud Classification System (PERSIANN-CCS) (Hong et al., 2004; Katsanos et al., 2004), the Global Precipitation Measurement (GPM) Integrated Multi-satellite Retrievals (IMERG) (Huffman et al., 2013) and the Support to Nowcasting and Very Short Range Forecasting Satellite Application Facility (NWC SAF) Convective Rainfall Rate (CRR) and Convective rainfall Rate from Cloud Physical Properties (CRR-Ph) products (Karagiannidis et al., 2021; Marcos et al., 2015).

GPM-IMERG contains significant random and systematic errors, which are accounted in the indirect nature of precipitation measurement (Aghakouchak et al., 2012; Sun et al., 2018). Previous studies have evaluated the GPMIMERG product against ground-based precipitation measurements at regional scale (Kazamias et al., 2017; Maghsood et al., 2020; Xu et al., 2019). Most of these studies delt with the assessment of GPM-IMERG at daily or monthly scale and only few of them examined its performance at a sub-daily scale (Freitas et al., 2020; Manz et al., 2017), which is much more suitable for flash flood phenomena. These studies revealed that GPM-IMERG tends to overestimate low rainfall events and is not able to capture heavy precipitation events (Alsumaiti et al., 2020). Furthermore, only few studies explored the applicability of satellite-based precipitation products for event-based hydrological modelling of flash floods in mountainous catchments (Gilewski and Nawalany, 2018; Varlas et al., 2017).

The objective of the current study is to examine the potential contribution of satellite precipitation data to the estimation of the peak discharges of flash flood events in ungauged Mediterranean watersheds. The proposed methodology was applied to small ungauged watersheds, in order to investigate the mechanisms of the devastating flash flood phenomena that took place in Thasos Island (Northern Greece) in November of 2019 and to evaluate the applicability of satellite precipitation data, in the hydrological modeling of such type of flood events. Specifically, the rain gauge measurements are correlated to the respective satellite precipitation data in the terms of a created grid of different GPM-IMERG cells. The optimum detected regression equation (of the strongest correlation level and the highest $\mathrm{R}^{2}$ ) is utilized in order to correct and adjust the satellite precipitation data of the rest flooded area in order to optimize the accuracy and reliability of the hydrological modeling (flood analysis). The proposed methodology aims to contribute to the thorough comprehension of flood mechanisms and the assistance to hydrologists, researchers and policy makers, providing new tools towards the improvement of the flood prevent measures efficiency and flood risk mitigation in ephemeral ungauged streams of Mediterranean area.

\section{Materials and methods}

\subsection{Study area description}

Hydrological modeling was applied in six typical Mediterranean watersheds, located in Thasos Island (Northern Greece) (Figure 1), which experienced intense flash food phenomena of catastrophic impact in November of 2019 (Figure 2). The number of permanent residents of Thasos is 13770, though during the summer touristic season, the population immensely increases. The total watershed area is $117.32 \mathrm{~km}^{2}$ and the headwaters of the six streams are located to Ypsarion mountain range at 1204 $\mathrm{m}$ a.s.l., the main streams flow towards different directions, pass through the Limenas, Panagia, Potamia, Potos and Limenaria settlements and flow into Aegean Sea (Mediterranean Sea) (Figure 1).

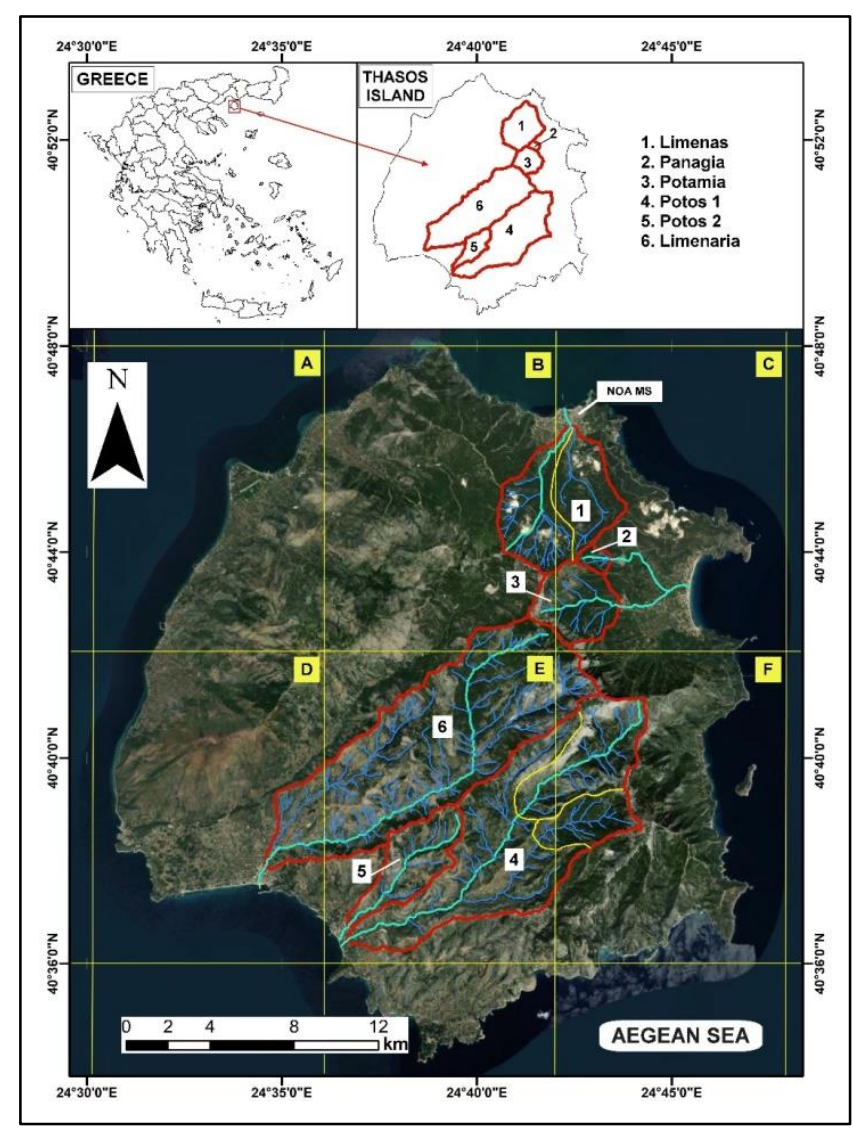

Figure 1. Study area. The yellow frames represent the GPMIMERG cells used is this study.

The relief of the watersheds could be characterized as steep, with an average slope higher than $39 \%$, though with significant variation among the different watersheds (Table 
1). Approximately $34 \%$ of the study area is covered by sclerophyllous vegetation, $21 \%$ by forest (mainly coniferous), $20 \%$ by transitional woodland-shrub, the burnt area covers almost $10 \%$ of the area and the rest $15 \%$ is covered by settlements, bare rocks and mineral extraction sites. The dominant rock is gneiss covering about of $52 \%$ of the study area, while $41 \%$ of the area is formed by limestones. Most of gneiss lithological types are easily weathered and covered by loose weathering mantle of ranging thickness, resulting in the manifestation of springs of usually low yield, in its contact with the intact rock (IGME, 1993). The formation of drainage network is dendritic, the density of drainage network ranges between $1.5-2.5 \mathrm{~km} / \mathrm{km}^{2}$ and the average mainstream slope is $12.9 \%$ (Table 1). The drainage network density is low, a fact that is attributed mainly to the presence of erosion resistant rocks (gneiss) and the dense forest coverage in intense inclined slopes.

Table 1. Morphometric and hydrographic characteristics of the examined watersheds

\begin{tabular}{|c|c|c|c|c|c|c|c|}
\hline Watersheds & $\begin{array}{l}\text { Area } \\
\left(\mathrm{km}^{2}\right)\end{array}$ & $\begin{array}{l}\text { Main stream } \\
\text { length }(\mathrm{km})\end{array}$ & $\begin{array}{c}\text { Drainage } \\
\text { network density } \\
\left(\mathrm{km} / \mathrm{km}^{2}\right)\end{array}$ & $\begin{array}{l}\text { Min } \\
\text { altitude }(m)\end{array}$ & $\begin{array}{c}\text { Max altitude } \\
\text { (m) }\end{array}$ & $\begin{array}{c}\text { Mean } \\
\text { altitude }(m)\end{array}$ & $\begin{array}{l}\text { Main stream } \\
\text { mean slope (\%) }\end{array}$ \\
\hline Limenas & 15.36 & 5.6 & 1.99 & 10.2 & 1108.9 & 346.4 & 15.93 \\
\hline M. Panagia & 0.86 & 1.7 & 2.52 & 264.0 & 805.0 & 445.0 & 26.79 \\
\hline Potamia & 6.60 & 3.0 & 1.83 & 119.0 & 1204.2 & 556.0 & 20.40 \\
\hline Potos 1 & 40.43 & 15.4 & 1.7 & 5.2 & 901.9 & 198.3 & 4.35 \\
\hline Potos 2 & 7.54 & 6.4 & 1.77 & 12.2 & 413.1 & 215.4 & 4.61 \\
\hline Limenaria & 46.6 & 16.2 & 2.28 & 10.9 & 1204.2 & 513.7 & 5.29 \\
\hline
\end{tabular}

\subsection{The extreme rainfall event and the flash flood of November 2019}

On $19^{\text {th }}$ of November, a low-pressure system was evident over Italy. The system moved gradually towards the Balkans, forming a semi stationary front and a low-pressure system over Greece that affected the area from $20^{\text {th }}$ to $22^{\text {nd }}$ of November. Southerly flow in the middle and lower troposphere advected warm and moist Mediterranean air masses towards the front, providing the necessary ingredients for the development of heavy rainfall and thunderstorms. The frontal zone along with the lowpressure system dissolved on $23^{\text {rd }}$ of November, and precipitation in the island ceased. During that period, the National Observatory of Athens Meteorological Station (NOA MS) located in Limenas settlement, recorded a total of $287 \mathrm{~mm}$ of precipitation.

In this study, we used the latest GPM-IMERG version 6 (V06B) Final Run products. IMERG-Final has two fields with multi-satellite precipitation estimates, precipitationCal and precipitationUncal. The difference between the two is the gauge calibration from the Global Precipitation Climatology Centre (GPCC) monthly Monitoring Product.

GPM-IMERG V06 uncalibrated precipitation rate data were analyzed from November $20^{\text {th }}$ to November $27^{\text {th }}$, aiming to highlight the precipitation regime during the two main flooding episodes. Precipitation in the island started around 21:30 (local time) of November $20^{\text {th }}$ and continued until midday of November $21^{\text {st }}$. Phenomena resumed late in the afternoon and continued until the late hours of November $22^{\text {nd }}$, but they were intermittent and in general, weaker. Around the time of the first wave of floods specifically, heavy precipitation affected the northern and eastern parts of the island for three and a half hours (01:00 $-04: 30$ of November $21^{\text {st }}$ ) (Figure 3). During that time, NOA MS recorded a total of $64 \mathrm{~mm}$ of precipitation. Strong precipitation also occurred from 09:30 to 13:00 but affected mainly the southern and southeastern parts of the island. Before Thasos, the first wave of the two storms hit
Chalkidiki region, generating very intense flood phenomena (Kastridis et al., 2020).
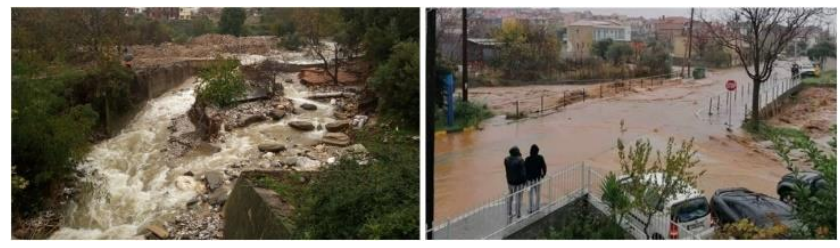

Figure 2. Representative pictures of the devastation in Thasos Island. Damaged bridge in Potamia settlement (left), overtopped bridge in Limenaria settlement (right).
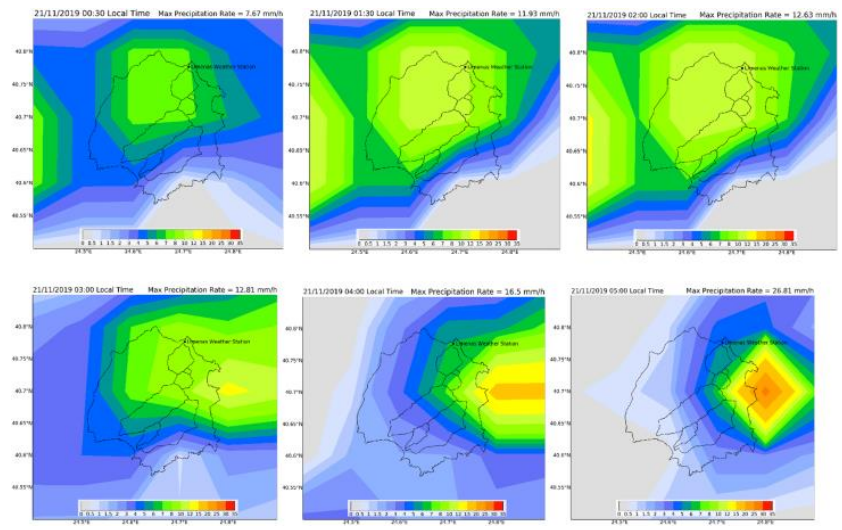

Figure 3. Spatial distribution of precipitation rate $(\mathrm{mm} / \mathrm{h})$ during the first flood event (21 November 2019, 00:30-05:00) using GPM-IMERG final uncalibrated data.

A low-pressure system approached the western parts of Greece on $24^{\text {th }}$ of November, and then, followed a northwest-southeast track. Due to its forecast intensity, the storm was named "Gyrionis" by the METEO unit of the National Observatory of Athens, after the Greek mythological giant. Storm Gyrionis produced heavy precipitation and gale force winds in many parts of Greece, unfortunately leaving 3 fatalities in its wake. The warm waters of the Aegean Sea contributed significantly to the formation of a secondary surface low with an occluded 
front on November $25^{\text {th }}$. The center of secondary low moved rapidly to northeast just offshore of the island of Thasos, reaching the coasts of Turkey on November $26^{\text {th }}$. During its course, the system produced strong convective activity and high amounts of precipitation in the island (NOA MS recorded a total of $185 \mathrm{~mm}$ ) from noon of $25^{\text {th }}$ of November to noon of $26^{\text {th }}$ of November.

According to GPM-IMERG estimations, the northern parts of the island received small amounts of precipitation from midday November $25^{\text {th }}$ to 01:00 of November $26^{\text {th }}$, when significant convective activity affected the island. Although the higher amounts of precipitation are located in the northwestern and southeastern parts of the island, the rest of the island also received high amounts of precipitation (Figure 4). To support this suggestion, the recordings of the Limenas weather station are referred, which from 01:00 to 06:00 of November $26^{\text {th }}$, when the convective activity was significantly weakened, accumulated around $120 \mathrm{~mm}$ of precipitation. These high amounts of water in combination with the precipitation and floods that affected Thasos in the previous days, led to a second wave of flood events.

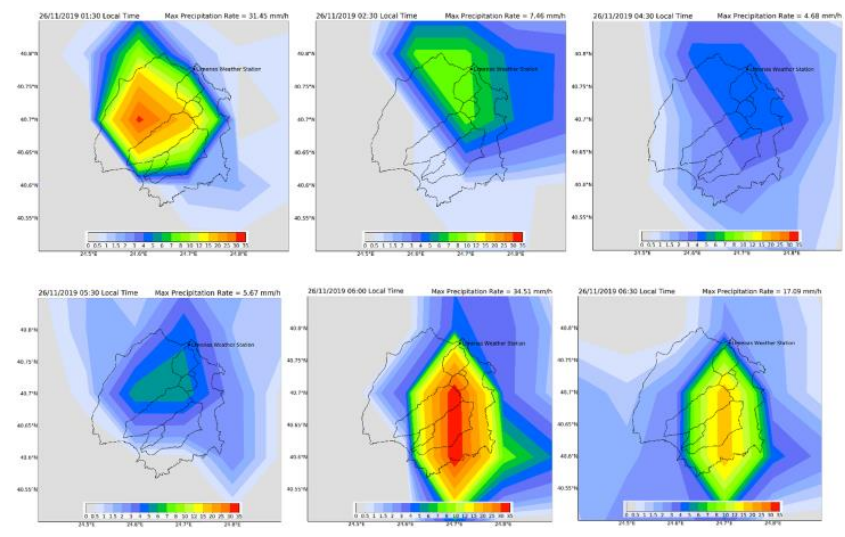

Figure 4. Spatial distribution of precipitation rate $(\mathrm{mm} / \mathrm{h})$ during the second flood event (26 November 2019, 01:30-06:30) using GPM-IMERG final uncalibrated data.

\subsection{Rainfall data - Satellite (GPM-IMERG) precipitation adjustment/correction}

In Thasos Island, there is only one Meteorological Station (MS) in operation, which is under the supervision of the National Observatory of Athens (NOA) (Lagouvardos et al., 2017). The NOA MS is located in the north part of Thasos and specifically, at the town hall of Limenas settlement (Figure 1). Therefore, the biggest part of Thasos Island is ungauged, concerning both precipitation and water discharge data. The most common approach to reconstruct the flood hydrograph in ungauged watersheds is the use of the available rainfall data from the closest MS but accepting the high hydrological uncertainties. To address this problem, satellite rainfall data could be used as an input in hydrological models. In the current study, GPMIMERG rainfall data were utilized to reconstruct the rainfall event's hyetographs over the six examined ungauged watersheds. Unfortunately, in Thasos or close to Thasos Island there is no radar, which would otherwise provide more accurate rainfall data. From the preliminary hydrological analysis, using the satellite data, it was revealed that the peak discharges were very low to explain the magnitude of the devastation in the watersheds. Despite that the total precipitation estimated by the satellite was high, the rainfall intensity $(\mathrm{mm} / 30 \mathrm{~min})$ was too low, compared with the NOA MS data (Figures 5 and 6 ).

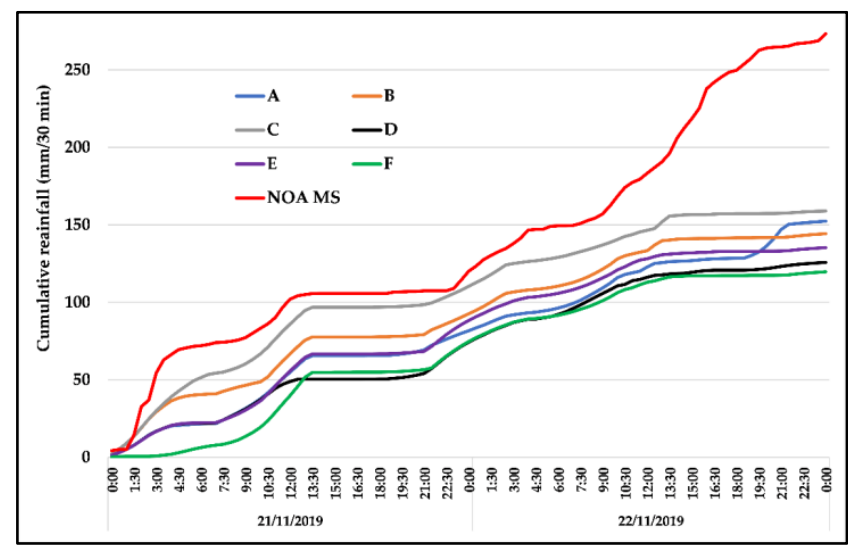

Figure 5. Cumulative rainfall $(\mathrm{mm})$ recorded from GPM-IMERG uncalibrated data and NOA MS during 21-22 November 2019 (the capital letters represent the cumulative rainfall from the GPM-IMERG cells that cover the study area-see Figure 1 ).

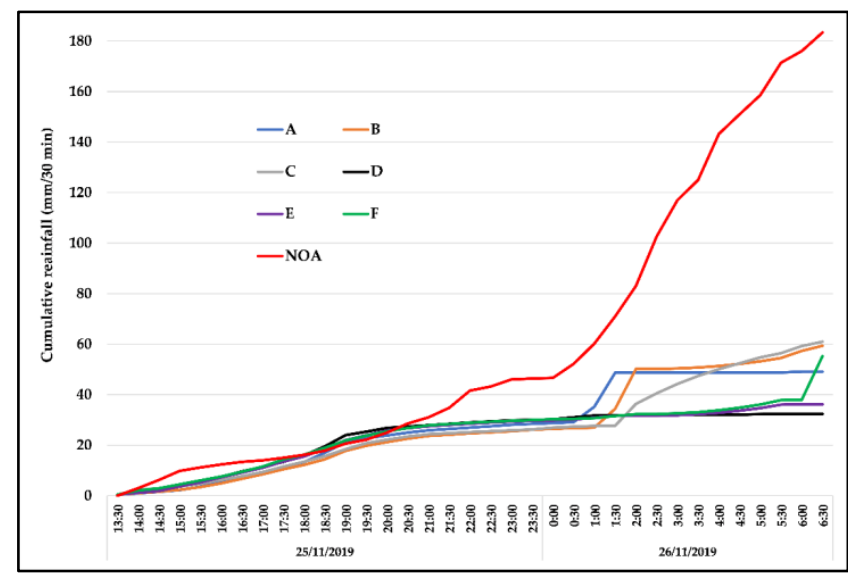

Figure 6. Cumulative rainfall $(\mathrm{mm})$ recorded from GPM-IMERG uncalibrated data and NOA MS during 25-26 November 2019 (the letters represent the cumulative rainfall from the GPMIMERG cells that cover the study area-see Figure 1).

To improve the satellite data, the cumulative precipitation heights $(\mathrm{mm})$ from NOA MS and the respective GPMIMERG cell (cell C, Figure 1) were correlated in a scatter plot (Diss et al., 2009; Gires et al., 2014). Different regression equations were tested (exponential, logarithmic, polynomial etc.), but linear regression showed the best fit, between the satellite data and the rain gauge measurements (cumulative rainfall). Additionally, the linear regression is the most commonly and widely used method, applied to compare ground and satellite data and adjust the satellite data (Gires et al., 2014; Liu et al., 2020; $\mathrm{Ma}$ et al., 2021). The resulted linear equations from the GPM-IMERG " $C$ " cell, presenting the highest correlation level, were used to adjust/correct the satellite data in cell " $C$ ". To check the validity of the adjustment in cell $C$, the 
RMSE-observations standard deviation ratio (RSR) (Moriasi et al., 2007), Nash and Sutcliffe Efficiency (NSE) (Nash and Sutcliffe, 1970) and the Percent bias (PBIAS) (Moriasi et al., 2007) goodness of fit indexes were applied to statistically compare the observed rainfall data (NOA MS) and the respective corrected satellite data (GPM-IMERG cell C). The calculated reliable linear equations obtained by GPMIMERG " $C$ " cell, were extrapolated and applied to the rest of the GPM-IMERG cells (A, B, D, E and F cells, Figure 1), which afterwards were used to the hydrological modeling of the ungauged watersheds. The extrapolation of the linear equations was performed to correct and adjust the rest GPM-IMERG cells that cover the study area. The proposed methodology could be applied to analyze extreme rainfall events, when the space-time distribution of the rainfall is relatively homogenous within the study area and the value of the coefficient of determination is high enough $\left(R^{2}>0.65\right)$.

\subsection{Hydrological modeling of November 2019 flash flood}

The rainfall-runoff model of Soil Conservation ServiceCurve Number (SCS-CN) (SCS, 1972) model was applied to calculate the flood hydrographs, using the software of the Hydrologic Modelling System (HEC-HMS, 2016). The small size of some sub-catchments could create uncertainties in hydrological model. However, it is very usual, the watersheds to consist of numerous small (or very small) sub-catchments, but when performing a hydrological modeling, these sub-catchments are not modeled separately. In order to alleviate this problem, HEC-HMS provides a model option (peak rate factor), which adjust the hydrograph, taking into account the steepness and the size of the watersheds. The rainfall data from NOA MS and the corrected satellite data were used as input precipitation data in the hydrological model. As it is evident in Figures 3 and 4, the rainfall intensity varied among and within the watersheds during the rainfall event. Thus, to improve the accuracy of the hydrological modeling, the watersheds were divided into smaller sub-catchments according to the spatial distribution of the rainfall intensity, which was derived from the GPM-IMERG observations (Figures 3 and 4). The SCS-CN rainfall-runoff model was applied to reconstruct the flash flood hydrographs of November 2019 in the study area. SCS-CN is a widely applied and well-known hydrological model worldwide (Rezaei-Sadr, 2017; Verma et al., 2017), applied also in Greece (Kastridis and Stathis, 2020; Soulis, 2018; Stathis et al., 2010). The $\mathrm{CN}$ is a dimensionless empirical parameter, which ranges from 30 to 100 (the highest numbers indicate high runoff potential), and estimates the runoff and infiltration from rainfall excess. The $\mathrm{CN}$ is categorized in three types (CNI, CNII and CNIII), according to the initial soil humidity or Antecedent Moisture Condition (AMC). There are three groups of AMCs (AMCI, AMCII and AMCIII, Table $2)$, according to the 5-day antecedent rainfall $(\mathrm{mm})$ and the season of the year. The main components of HEC-HMS software were set as following: CN (loss method), SCS unit hydrograph (transform method) and no baseflow method (ephemeral streams) was applied. The SCS-CN model was previously calibrated and validated at Vatonias watershed (north Greece), which corresponds to similar land-use type and geomorphologic conditions (Kastridis and Stathis, 2020). Additionally, the calibrated hydrological model was again validated at Olympiada watershed (north Greece), for the same extreme rainfall event (November 2019) (Kastridis et al., 2020).

The empirical equation (1) developed in the framework of the "Deucalion Project" (Efstratiadis et al., 2019) was used to calculate the CNII, 20 parameters (for initial loss rate of $20 \%$ and group AMCII average humidity conditions):

$$
\text { CNII, } 20=10+9 * \text { iPERM }+6 * \text { iVEG }+3 * \text { iSLOPE }
$$

where: IPERM (water permeability), iVEG (vegetation density) and iSLOPE (drainage capability) are variables with values ranging between 1 and 5 , according to the related tables (Efstratiadis et al., 2019) and field research. The CNII,20 was calculated using raster files and GIS techniques (Tzioutzios and Kastridis, 2020). CN is highly influenced by the Antecedent Moisture Conditions (AMC), which corresponds to the total precipitation recorded 5 days before the storm event (Table 2).

Table 2. Classification of antecedent moisture condition classes (AMC) for the SCS method of rainfall abstractions (source: Chow et al., 1988; table 5.5.1, p. 149).

\begin{tabular}{ccc}
\hline AMC group & \multicolumn{2}{c}{ Total 5-day antecedent rainfall (mm) } \\
\hline I & Dormant season & Growing season \\
\hline II & Less than 13 & Less than 35 \\
\hline III & 13 to 28 & 35 to 53 \\
\hline
\end{tabular}

$\mathrm{CNII,20}$ is the reference value and corresponds to average humidity conditions (AMC II) and initial loss rate of $20 \%$. According to empirical equations, the value of $\mathrm{CNII}, 20$ (AMC II) is related to the other two typical types (AMCI and AMC III) of initial soil moisture conditions as following (Chow et al., 1988):

$$
\begin{aligned}
& \mathrm{CNI}=\frac{\left(4.4^{*} \mathrm{CNII}\right)}{\left(10-0.058^{*} \mathrm{CNII}\right)} \\
& \mathrm{CNI}=\frac{\left(23^{*} \mathrm{CNII}\right)}{\left(10+0.13^{*} \mathrm{CNII}\right)}
\end{aligned}
$$

In the current study, CNIII type was applied in the hydrological modeling, since the flood event took place in the dormant season (November) and the total 5-day antecedent rainfall was over $28 \mathrm{~mm}$.

Giandotti formula [Equation (4)] was used to estimate the concentration time ( $t_{c}$ ) (Giandotti, 1934). Previous studies refer that Giandotti formula is considered to be more reliable in Mediterranean watershed conditions (Michailidi et al., 2018):

$$
t_{\mathrm{c}}=\frac{(4 \sqrt{F}+1.5 L)}{(0.8 \sqrt{H-h}))}
$$

where, $t_{c}$ : the time of concentration (hours).

$F$ : watershed area $\left(\mathrm{km}^{2}\right)$.

$L$ : the mainstream length $(\mathrm{km})$.

$H$ : the mean watershed elevation (m). 
$h$ : the watershed outlet elevation (m).

The lag time $\left(t_{L}\right)$ was calculated in relation to the time of concentration $\left(t_{c}\right)$, using the following equation of United States Department of Agriculture (USDA, 2010):

$$
t_{\mathrm{L}}=0.6 * t_{\mathrm{c}}
$$

where, $t_{L}$ : the lag time (hours).

$t_{c}$ : the time of concentration (hours).

Information about the vegetation was obtained from the CORINE land cover database (EEA, 2012), and a process to correct the boundaries of CLC polygons (codes 243 and 324) was performed, applying photointerpretation of aerial orthoimages provided by the Hellenic Cadastre. Field surveys and geological maps $(1: 50,000)$ provided by the Institute of Geology and Mineral Exploration of Greece were used to determine the geological and soil characteristics of the study area.

The RMSE-observations standard deviation ratio (RSR) (Gilewski and Nawalany, 2018), Nash and Sutcliffe Efficiency (NSE) (Nash and Sutcliffe, 1970) and the Percent bias (PBIAS) goodness of fit indexes were used to statistically compare the flood hydrographs, which were calculated using the NOA MS rainfall data and the respective corrected satellite data based on GPM-IMERG " $C$ " cell regression equations.

\subsection{Validation of the methodology-field measurements}

To validate the results of the hydrological modeling and minimize the model uncertainties, the peak flow water discharge was calculated in stable cross sections (culverts and bridges), using the High Water Marks (HWMs) that were visible immediately after the flash flood event. The days after the flood event of November 2019, a field survey was organized with the aim to record data that were associated to the flow depth in stable stream crosssections. United States Geological Survey (USGS) Techniques and Methods 3-A24 handbook (Koenig et al.,
2016) was used as a guide, to minimize the subjectivity bias. The field research emphasized on High Water Marks (HWMs) that involved lines of dried mud on surfaces, debris lines, seed lines, wash lines, debris snags, leaves, branches or pine straw stuck in several places. The highwater velocity and high sediment load during flood episodes usually create wave action, pileup and runup on various obstructions, which could cause misleading highwater marks (Diakakis et al., 2019). For that reason, water depth was measured in locations without obstacles and with relatively low water flow velocity. Using the data from the cross sections, the maximum water discharge was calculated applying the Manning equation (Manning, 1891) (6):

$$
\begin{aligned}
& u=\frac{1}{n} * R^{\frac{2}{3}} * J^{\frac{1}{2}} \\
& Q=F^{*} u
\end{aligned}
$$

where, $u$ : water velocity $(\mathrm{m} / \mathrm{s})$

$R$ : hydraulic radius $(\mathrm{R}=\mathrm{F} / \mathrm{U})$

$F$ : cross section area $\left(\mathrm{m}^{2}\right)$

$U$ : cross section wetted perimeter $(\mathrm{m})$

$\mathrm{J}$ : energy grade line slope $(\mathrm{m} / \mathrm{m})$

$n$ : Manning's roughness coefficient (HEC-RAS user's manual, 2010)

Q: water discharge $\left(\mathrm{m}^{3} / \mathrm{s}\right)$

Using the hydraulic characteristics of the selected cross sections and the equation (6), the maximum water discharge was calculated for each cross section and presented in Table 3. The exact coordinates (WGS84) of the cross sections are the following: Limenas $\left(40^{\circ} 46^{\prime} 30.9^{\prime \prime} \mathrm{N}\right.$, $\left.24^{\circ} 42^{\prime} 22.9^{\prime \prime} \mathrm{E}\right), \quad$ Panagia $\left(40^{\circ} 43^{\prime} 51.8^{\prime \prime} \mathrm{N}, \quad 24^{\circ} 43^{\prime} 32.7^{\prime \prime} \mathrm{E}\right)$, Potamia $\left(40^{\circ} 42^{\prime} 57.2^{\prime \prime} \mathrm{N}, \quad 24^{\circ} 43^{\prime} 38.1^{\prime \prime} \mathrm{E}\right), \quad$ Potos 1 $\left(40^{\circ} 36^{\prime} 26.7^{\prime \prime} \mathrm{N}, 24^{\circ} 36^{\prime} 40.4^{\prime \prime} \mathrm{E}\right)$, Potos 2 (40³6'39.8"N,

\begin{tabular}{|c|c|c|c|c|c|c|c|}
\hline $\begin{array}{c}\text { Hydraulic } \\
\text { characteristics }\end{array}$ & $\begin{array}{c}\text { Streambed } \\
\text { slope J } \\
\text { (m/m) }\end{array}$ & $\begin{array}{c}\text { Wetted } \\
\text { perimeter U } \\
\text { (m) }\end{array}$ & $\begin{array}{c}\text { Manning's } \\
\text { roughness } \\
\text { coefficient } \\
\text { (n) }\end{array}$ & $\begin{array}{c}\text { Cross section } \\
\qquad F\left(m^{2}\right)\end{array}$ & $\begin{array}{l}\text { Hydraulic } \\
\text { radius } R \\
\text { (m) }\end{array}$ & $\begin{array}{c}\text { Water } \\
\text { velocity u } \\
(\mathrm{m} / \mathrm{s})\end{array}$ & $\begin{array}{c}\text { Water } \\
\text { discharge Q } \\
\left(\mathrm{m}^{3} / \mathrm{s}\right)\end{array}$ \\
\hline $\begin{array}{l}\text { 1. Limenas - } \\
\text { main stream }\end{array}$ & 0.018 & 13.40 & 0.033 & 22.40 & 1.67 & 5.65 & 126.6 \\
\hline $\begin{array}{l}\text { 2. Panagia - } \\
\text { main stream }\end{array}$ & 0.120 & 6.50 & 0.020 & 1.50 & 0.23 & 6.58 & 9.9 \\
\hline $\begin{array}{l}\text { 3. Potamia - } \\
\text { culvert }\end{array}$ & 0.080 & 8.80 & 0.033 & 9.68 & 1.10 & 9.04 & 87.5 \\
\hline $\begin{array}{l}\text { 4. Potos } 1 \text { - } \\
\text { bridge }\end{array}$ & 0.006 & 30.00 & 0.040 & 88.00 & 2.93 & 3.9 & 346.7 \\
\hline $\begin{array}{l}\text { 5. Potos } 2 \text { - } \\
\text { culvert }\end{array}$ & 0.013 & 13.40 & 0.033 & 19.80 & 1.48 & 4.43 & 87.6 \\
\hline $\begin{array}{l}\text { 6. Limenaria - } \\
\text { bridge }\end{array}$ & 0.013 & 28.40 & 0.028 & 52.80 & 1.86 & 6.01 & 317.3 \\
\hline
\end{tabular}
$\left.24^{\circ} 36^{\prime} 36.2^{\prime \prime} \mathrm{E}\right)$ and Limenaria (40 $\left.37^{\prime} 47.5^{\prime \prime} \mathrm{N}, 24^{\circ} 34^{\prime} 29.4^{\prime \prime} \mathrm{E}\right)$.

Table 3. Hydraulic characteristics and the maximum discharge of the examined cross sections

\section{Results and discussion}

3.1. Satellite (GPM-IMERG) precipitation calibration
The cumulative rainfall data from NOA MS and GPM-IMERG (" $C$ " cell) were correlated in a scatter plot, in order to examine if there is any significant statistical relation. This 
correlation of rainfall events showed strong and significant $\left(R^{2}>0.85\right)$ linear relation (Figure 7$)$ between cumulative precipitation data from NOA MS and GPM-IMERG ("C' cell).

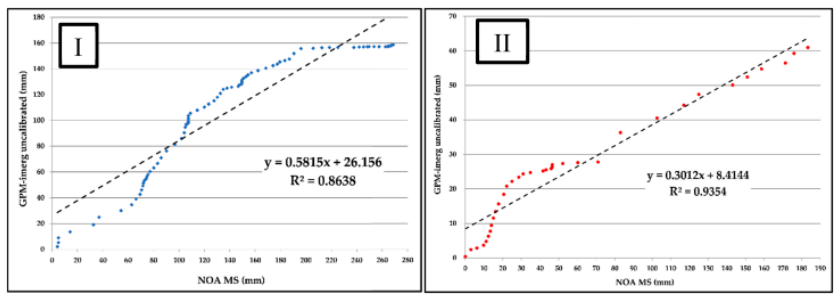

Figure 7. Correlation of the cumulative precipitation heights $(\mathrm{mm})$ between NOA MS and GPM-IMERG - "C" cell (I. 21-23 November, II. 25-26 November).

The different correlation coefficients $\left(R^{2}\right)$ of the two storms are normal and expected, since each rainfall event presents different space-time characteristics. However, $\mathrm{R}^{2}$ for both correlations was higher than 0.65 , a value that is acceptable for model calibration (Moriasi et al., 2007; Van Liew et al., 2003). The resulted linear equations (Figure 7) were applied to adjust/correct the rainfall data of the rest GPM-IMERG cells (A, B, D, E and F cells) that cover the flooded area.

To validate the adjustment method of the GPM-IMERG rainfall, a statistical analysis was performed. Regarding the comparison between the observed (NOA MS) and adjusted (GPM-IMERG, "C" cell) cumulative rainfalls (Figure 8), the RSR was calculated to be 0.78 . According to the literature, RSR values close to zero indicate perfect model validation, while high positive values could be considered as unacceptable (Moriasi et al., 2007). Likewise, the NSE was calculated to be 0.31 , a value that may not be the optimal, but is acceptable for model validation. NSE optimal value is 1 , while it ranges between $-\infty$ and 1 , and values between 0-1 could be considered as acceptable (Moriasi et al., 2007). Values $\leq 0$ suggest that the model performance is unacceptable (Moriasi et al., 2007).

PBIAS is a statistic index that measures the average tendency of the modeled values to be higher or lower than their observed counterparts (Gupta et al., 1999). The PBIAS was calculated to be $-3.71 \%$, which is a very low value. Gupta et al. (1999) stated that PBIAS optimal value is 0, while positive values indicate model underestimation bias and negative values model overestimation bias. Values of PBIAS between $15 \%$ and $-15 \%$ could be considered acceptable for model validation (Moriasi et al., 2007; Singh et al., 2005; Van Liew et al., 2003). The results of RSR and NSE statistic indexes showed a quite low difference between the observed and adjusted/corrected rainfalls and according to the PBIAS (-3.71\%), there is a very slight overestimation of the adjusted values. The strong correlation detected in GPM-IMERG " $C$ " cell, allowed the implementation of the two linear equations (Figure 7) to adjust the rest of the GPM-IMERG cells of the study area, which were used in the hydrological modeling.

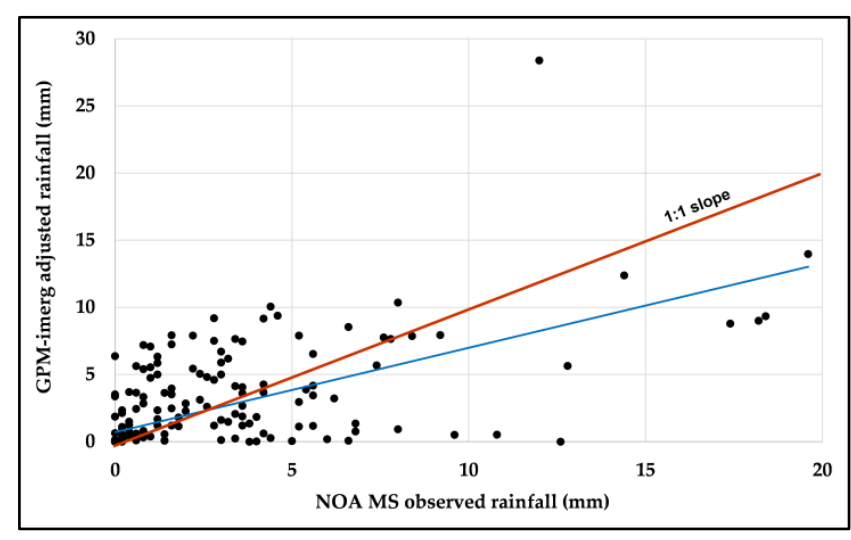

Figure 8. Scatter plot of the observed (NOA MS) and adjusted (GPM-IMERG, "C" cell) values of rainfall. The blue line depicts the linear correlation of the data.

\subsection{Hydrological modeling}

The flood simulation for each watershed was implemented using three data sources, NOA MS, GPM-IMERG uncalibrated rainfall and GPM-IMERG adjusted rainfall. The initial flood simulation was conducted in Limenas watershed, where the NOA MS is located and reliable comparison among the three flood hydrographs could be achieved, using the rain gauge observations. According to the results of the hydrological simulations (Figure 9), there is a significant similarity between the NOA MS and the adjusted GPM-IMERG flood hydrographs. The similarity of the flood hydrographs was even higher, concerning the time of peak flow and the values of peak discharge as shown in Figure 9 (26/11/2019-03:45). The time of peak discharge was also confirmed by the information provided by local sources/eyewitnesses (residents, videos and local authorities). However, the flood hydrograph revealed that the uncalibrated GPM-IMERG data failed to record the real magnitude of the flash flood event.

Accepting the NOA MS hydrograph as the "observed" hydrograph of Limenas watershed, RSR, NSE and PBIAS were computed to statistically compare the NOA MS hydrograph with the simulated hydrograph derived by the adjusted GPM-IMERG data (Figure 10). The RSR was calculated to be 0.62 , the NSE 0.61 and the PBIAS $-4.46 \%$. The results of the statistical comparison of the observed and simulated hydrographs showed that the hydrological simulation is successful, since the values of the statistic indexes (RSR, NSE, PBIAS) were within the acceptable range for model validation (Chow et al., 1988; Liu et al., 2020). The PBIAS was very low and revealed a slight overestimation of the adjusted GPM-IMERG hydrograph.

To validate the hydrological simulation, the maximum water discharge was calculated using the HWMs, which have been measured after the flood event in stable stream cross sections. According to the field measurements, the maximum flood discharge for Limenas watershed was $126.5 \mathrm{~m}^{3} / \mathrm{s}$, a value that is slightly higher than the calculated one from the hydrological simulation (Figure 9). These findings indicate that the hydrological simulation was successfully validated by the field data and the simulated maximum discharge was within an acceptable range of $\pm 20 \%$ error, which corresponds to a realistic 
uncertainty for hydrological modeling (Andreadakis et al., 2020; Anagnostou et al., 2013; Diakakis et al., 2019).

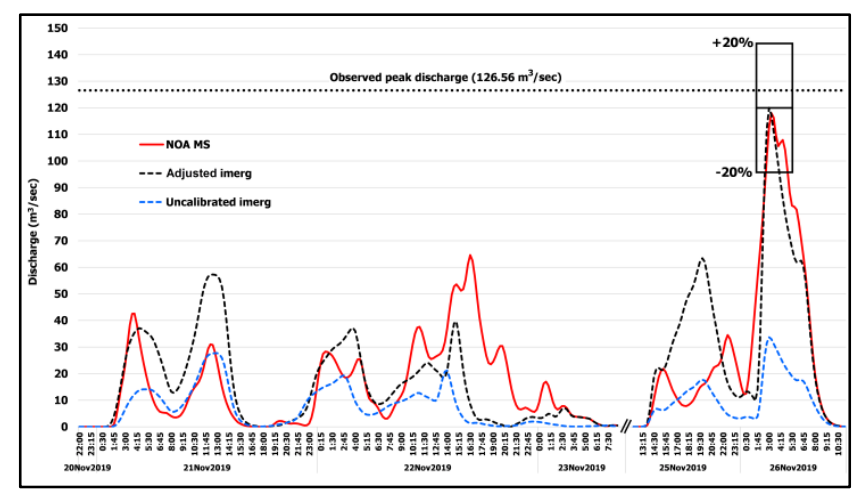

Figure 9. Simulated hydrographs at Limenas watershed using NOA MS, adjusted and uncalibrated GPM-IMERG rainfall data. The box area corresponds to the uncertainty of the simulated maximum discharge based on $\pm 20 \%$. The dot black line depicts the observed maximum discharge using the HWMs from the cross sections.

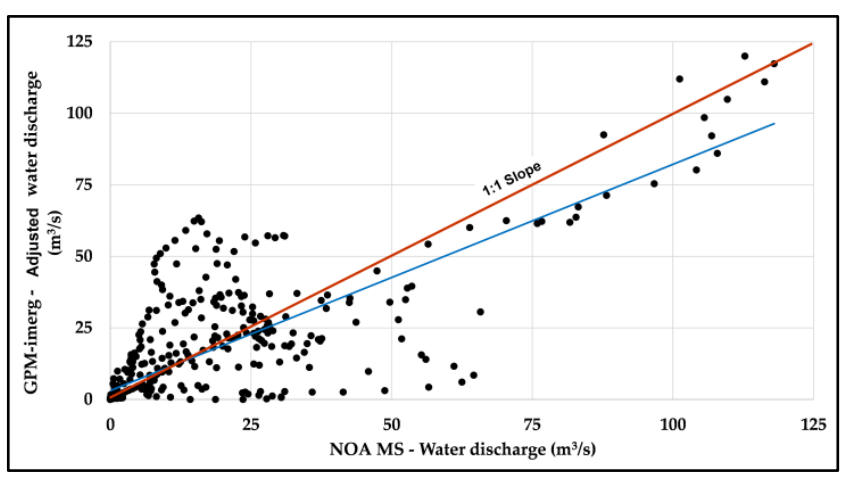

Figure 10. Scatter plot of the observed (NOA MS) and adjusted (GPM-IMERG) values of water discharge $\left(\mathrm{m}^{3} / \mathrm{s}\right)$. The blue line depicts the linear correlation of the data.

The rainfall data of the other GPM-IMERG cells that cover the study area, were also adjusted/corrected using the same linear equations (Figure 7), in order to perform the hydrological simulation in all the watersheds. As it is mentioned above, the watersheds were separated into sub-catchments according to the storm path and the height of rainfall that had been received, and not using the strict rectangle borders of GPM-IMERG cells. The results from the preliminary hydrological analysis, showed that the uncalibrated GPM-IMERG data were insufficient to explain the magnitude of the devastation in the watersheds of the study area and the calculated peak discharges values were very low in comparison to the observed peak discharges, calculated based on the HWMs. The results of the hydrological simulation, the maximum observed discharge and the $\pm 20 \%$ error for each watershed, are presented in the following Figures 11-15:

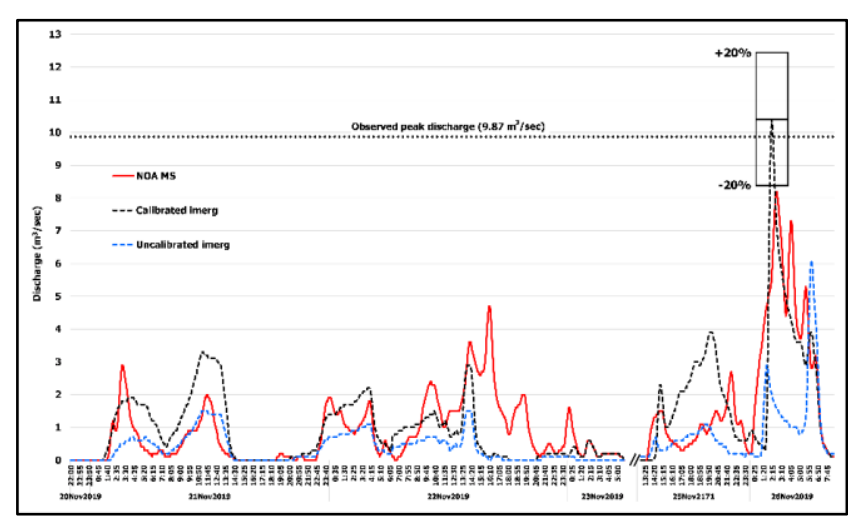

Figure 11. Simulated hydrographs of Panagia watershed using NOA MS, adjusted and uncalibrated GPM-IMERG rainfall data. The box area corresponds to the uncertainty of the simulated maximum discharge based on $\pm 20 \%$. The dot black line depicts the observed maximum discharge using the HWMs from the cross sections.

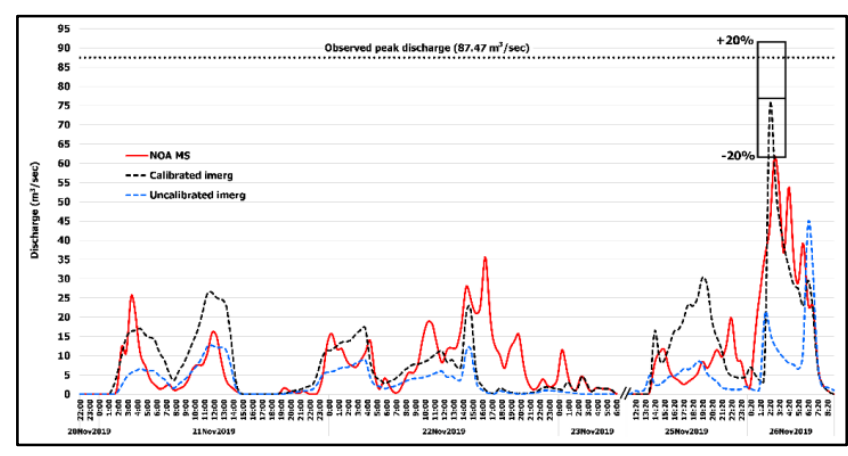

Figure 12. Simulated hydrographs of Potamia watershed using NOA MS, adjusted and uncalibrated GPM-IMERG rainfall data. The box area corresponds to the uncertainty of the simulated maximum discharge based on $\pm 20 \%$. The dot black line depicts the observed maximum discharge using the HWMs from the cross sections.

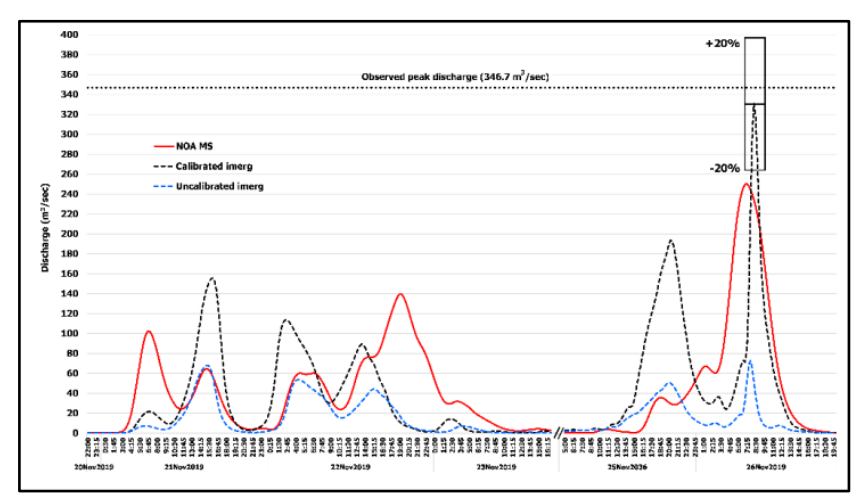

Figure 13. Simulated hydrographs of Potos 1 watershed using NOA MS, adjusted and uncalibrated GPM-IMERG rainfall data. The box area corresponds to the uncertainty of the simulated maximum discharge based on $\pm 20 \%$. The dot black line depicts the observed maximum discharge using the HWMs from the cross sections. 


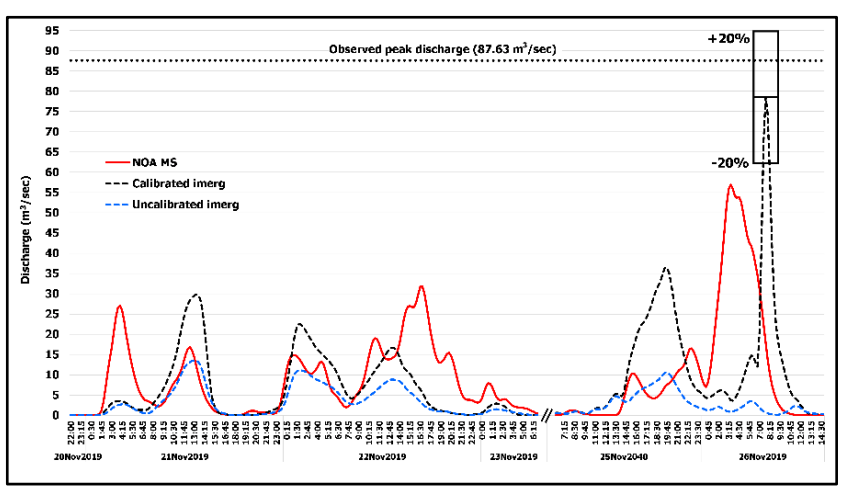

Figure 14. Simulated hydrographs of Potos 2 watershed using NOA MS, adjusted and uncalibrated GPM-IMERG rainfall data. The box area corresponds to the uncertainty of the simulated maximum discharge based on $\pm 20 \%$. The dot black line depicts the observed maximum discharge using the HWMs from the cross sections.

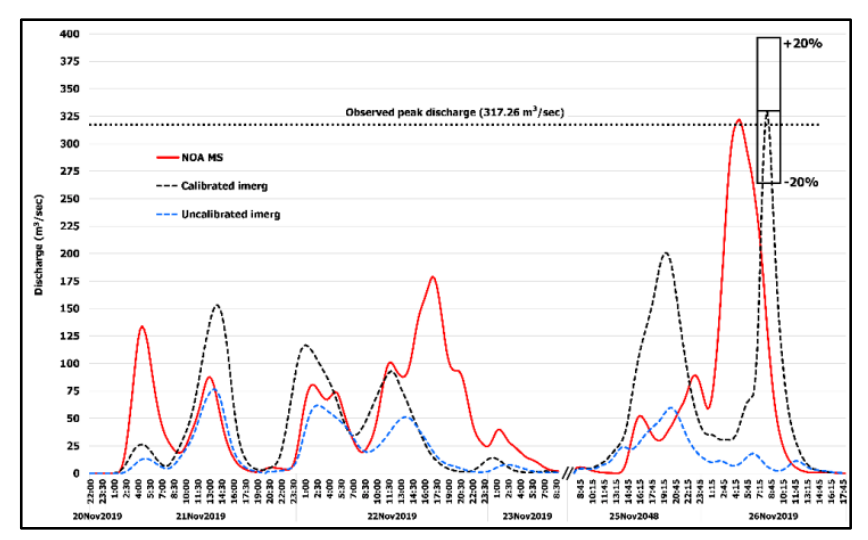

Figure 15. Simulated hydrographs of Limenaria watershed using NOA MS, adjusted and uncalibrated GPM-IMERG rainfall data. The box area corresponds to the uncertainty of the simulated maximum discharge based on $\pm 20 \%$. The dot black line depicts the observed maximum discharge using the HWMs from the cross sections.

According to the results, the specific discharge of the watersheds ranged between $7-13 \mathrm{~m}^{3} / \mathrm{s}$ per $\mathrm{km}^{2}$, with a mean value of $8.1 \mathrm{~m}^{3} / \mathrm{s}$ per $\mathrm{km}^{2}$. According to previous studies, specific discharge ranging between $8-11 \mathrm{~m}^{3} / \mathrm{s}$ per $\mathrm{km}^{2}$ is very common for flash flood events in Mediterranean watersheds (Diakakis et al., 2019; Gaume et al., 2009; Kastridis et al., 2020; Marchi et al., 2009).

In all watersheds (except Limenaria, Figure 15), the adjusted GPM-IMERG flood hydrographs predicted more accurately the observed peak discharge than the NOA MS and the uncalibrated GPM-IMERG hydrographs. The comparison between the adjusted GPM-IMERG and observed peak discharges showed that in all watersheds (except Panagia and Limenaria), there is an underestimation of the peak discharge. However, the uncertainties of the proposed methodology and the hydrological modeling are within a reasonable range between $\pm 20 \%$, which could be characterized as acceptable for hydrological modeling (Anagnostou et al., 2013; Andreadakis et al., 2020; Diakakis et al., 2019).
The option to perform hydrological analysis of a flash flood event, using rainfall data from rain gauges, which are located outside of the study area, is unreliable and could lead to misleading results. Except for Limenas watershed, in which NOA MS is located, in all the other watersheds the rain gauge data that were used in the hydrological modeling, failed to explain the observed peak discharges. Additionally, the use of NOA MS rainfall data in hydrological model, resulted in peak discharges that were very low, but within the acceptable error of $\pm 20 \%$. Rain gauge data are extremely useful for hydrological modeling of flood events in cases of rain gauges that are located within or very close to the study area. Furthermore, rain gauge data could be used for the validation and adjustment/correction of satellite data, prior to the hydrological analysis of a flood event. However, hydrological modeling using rainfall data from rain gauges that are located far away from the study area should not be a-priori discarded, although it may introduce a lot of uncertainties that should be thoroughly considered.

The hydrological analysis revealed that the uncalibrated GPM-IMERG rainfall data are not reliable to be used for the hydrological modeling of flash flood events, in small ungauged watersheds. In any case, the use of satellite rainfall data in hydrological modeling of flash flood events, should be implemented with caution and the resulting hydrographs should be validated against ground observations and measurements. Additionally, the results showed that the equation derived from the linear regression of the cumulative rainfalls, can be extrapolated, in order to adjust adjacent IMERG cells, providing very satisfying results. As a consequence, the proposed methodology can be applied in several other ungauged watersheds that have at least one rain gauge in close proximity and the linear regression between rain gauge and satellite data should achieve a coefficient of determination $\left(R^{2}\right)$ higher than 0.65 .

The main limitation of the proposed methodology is the availability of qualitative ground and satellite rainfall data. At least one rain gauge in close proximity with the study area should be present. Additionally, the spatiotemporal distribution of the extreme rainfall event should be relative homogenous over the flooded study area, a fact that is validated using the available satellite rainfall. Furthermore, the linear regression between rain gauge and satellite data should achieve a coefficient of determination $\left(R^{2}\right)$ higher than 0.65 , so that the correlation results to be considered as trustworthy and then the linear equations could be extrapolated to the adjacent watersheds.

\section{Conclusions}

The results of the hydrological modeling showed that the uncalibrated GPM-IMERG rainfall data cannot be used for the investigation of flash flood events in ungauged watersheds. Furthermore, the data coming from rain gauges are very useful to accurately predict the peak discharges in cases that the rain gauges are located within the study area. However, the uncertainties of the 
hydrological analysis are increased, in cases that the rain gauges are outside the catchment area.

The results of the hydrological analysis showed that the combination of the satellite spatiotemporal rainfall data and the ground rainfall data, could be very useful in flash flood analysis in ungauged watersheds. The adjustment of the GPM-IMERG rainfall data using the recorded rainfall from NOA MS, proved to be accurate in terms of rainfall spatiotemporal distribution and in terms of peak discharges, since the results of hydrological model showed that the calculated peak discharges were within an acceptable range of $\pm 20 \%$ and very close to the observed peak discharges of the examined watersheds. The proposed methodology could be very useful to hydrologists and policy makers that work on flood mitigation measures establishment, flood risk assessment, hydrological and hydraulic simulation of flash flood events in ungauged watersheds.

\section{References}

Aghakouchak A., Mehran A., Norouzi H. and Behrangi A. (2012). Systematic and random error components in satellite precipita-tion data sets. Geophysical Research Letters, 39, 36. doi: 10.1029/2012GL051592.

Alsumaiti T.S., Hussein K., Ghebreyesus D.T. and Sharif H.O. (2020), Performance of the CMORPH and GPM IMERG products over the United Arab Emirates. Remote Sensing, 12. doi: 10.3390/RS12091426.

Anagnostou M.N., Kalogiros J., Marzano F.S., Anagnostou E.N., Montopoli M. and Picciotti E. (2013). Performance evaluation of a new rain microphysics algorithm for dual-polarization $X$ band radars using long-term radar and disdrometer measurements. J. Hydro-meteorol., 14, 560-576, https://doi.org/10.1175/JHM-D-12-057.1.

Andreadakis E., Diakakis M., Vassilakis E., Deligiannakis G., Antoniadis A., Andriopoulos P., Spyrou N.I. and Nikolopoulos E.I. (2020), Unmanned Aerial Systems-Aided Post-Flood Peak Discharge Estimation in Ephemeral Streams. Remote Sensing, 12, 4183. https://doi.org/10.3390/rs12244183.

Behrangi A., Khakbaz B., Jaw T.C., AghaKouchak A., Hsu K. and Sorooshian S. (2011), Hydrologic evaluation of satellite precipitation products over a mid-size basin. Journal of Hydrometeorology, 397, 225-237. doi: 10.1016/j.jhydrol.2010.11.043.

Boithias L., Sauvage S., Lenica A., Roux H., Abbaspour K.C., Larnier K., Dartus D. and Sánchez-Pérez J.M. (2017). Simulating Flash Floods at Hourly Time-Step Using the SWAT Model. Water, 9, 929. https://doi.org/10.3390/w9120929.

Borga M., Anagnostou E.N., Blöschl G. and Creutin J.D. (2010). Flash floods: Observations and analysis of hydro-meteorological controls. Journal of Hydrology, 394(1-2), 1-284.

Chow V.T., Maidment D.R. and Mays L.W. (1988), Applied Hydrology, McGraw-Hill: New York, NY, USA, 1988, p. 572, ISBN 0 07-010810-2.

CORINE Land Cover. European Environment Agency (EEA) (2012), Available online: https://land.copernicus.eu/ paneuropean/corine-land-cover/clc-2012. (accessed on 15 October 2020).

Diakakis M., Andreadakis E., Nikolopoulos E.I., Spyrou N.I., Gogou M.E., Deligiannakis G., Katsetsiadou N.K., Antoniadis Z., Melaki M., Georgakopoulos A., et al. (2019), An integrated approach of ground and aerial observations in flash flood disaster investigations. The case of the 2017 Mandra flash flood in Greece. International Journal of Disaster Risk Reduction, 33, 290-309. doi:10.1016/j.ijdrr. 2018.10.015.

Diss S., Testud J., Lavabre J., Ribstein P., Moreau E. and Parent du Chatelet J. (2009). Ability of a dual polarized X-band radar to estimate rainfall. Advances in Water Resources, 32, 975-985. https://doi.org/10.1016/j.advwatres.2009.01.004.

Efstratiadis A., Koutsoyiannis D., Mamassis N., Dimitriadis P. and Maheras A. (2019). Literature Review of flood hydrology and related tools, deucalion-assessment of flood flows in greece under conditions of hydroclimatic variability: de-velopment of physically-established conceptual-probabilistic framework and computational tools. Available online: https://www.itia.ntua.gr/getfile/1215/1/documents/Report_ WP3_1_1.pdf (accessed on 13 November 2019).

Faccini F., Luino F., Paliaga G., Sacchini A. and Turconi L. (2015). Yet another disaster flood of the Bisagno stream in Genoa (Liguria, Italy): October the 9th-10th 2014 event. Rendiconti Online Societa Geologica Italiana, 35, 128-131. https://doi.org/10.3301/ROL.2015.81.

Freitas S., Hugo V. and Coelho R. (2020). The performance of the IMERG satellite-based product in identifying sub- daily rainfall events and their properties. Journal of Hydrology, 589, 125128. doi: 10.1016/j.jhydrol.2020.125128.

Gaume E., Bain V., Bernardara P., Newinger O., Barbuc M., Bateman A.,... and Viglione A. (2009). A compilation of data on Eu-ropean flash floods. Journal of Hydrology, 367(1), 70-78. https://doi.org/10.1016/j.jhydrol.2008.12.028.

Gaume E., Borga M., Llasat M.C., Maouche S., Lang M. and Diakakis M. (2016). Mediterranean extreme floods and flash floods. Into Hydrometeorological extremes, The Mediterranean Region under Climate Change. A scientific update, 2016 IRD Édi-tions Institut de Recherche pour le Développement. Marseille, 133-144.

Giandotti M. (1934). Previsione delle piene e delle magre dei corsi d'acqua. Ministero LL.PP. In Memorie e Studi Idro-grafici, Servizio Idrografico Italiano: Rome, Italy, p. 13. (In Italian)

Gilewski P. and Nawalany M. (2018). Inter-comparison of raingauge, radar, and satellite (IMERG GPM) precipitation estimates performance for rainfall-runoff modeling in a mountainous catchment in Poland. Water, 10, 1665. https://doi.org/10.3390/w10111665.

Gires A., Tchiguirinskaia I., Schertzer D., Schellart A., Berne A. and Lovejoy S. (2014). Influence of small scale rainfall variability on standard comparison tools between radar and rain gauge data. Atmospheric Research. 138, 125-138. https://doi.org/10.1016/j.atmosres.2013.11.008.

Gupta H.V., Sorooshian S. and Yapo P.O. (1999). Status of automatic calibration for hydrologic models: Comparison with multilevel expert calibration. Journal of Hydrological Engineering, 4(2), 135-143. https://doi.org/10.1061/ (ASCE)1084-0699(1999)4:2(135).

Hong Y., Hsu K.L., Sorooshian S. and Gao X. (2004). Precipitation estimation from remotely sensed imagery using an artificial neural network cloud classification system. Journal of Applied Meteorology, 43, 1834-1852. doi: 10.1175/jam2173.1

Hooke J.M. (2016). Geomorphological impacts of an extreme flood in SE Spain. Geomorphology, 263, 19-38. https://doi.org/10.1016/j.geomorph.2016.03.021. 
Huffman G., Bolvin D., Braithwaite D., et al. (2013), Algorithm Theoretical Basis Document (ATBD) NASA Global Precipitation Measurement (GPM) Integrated Multi-satellitE Retrievals for GPM (IMERG). NASA, NASA/GSFC, NASA/GSFC Code 612, Greenbelt, MD 20771.

Huffman G., Bolvin D., Nelkin E., et al. (2007), The TRMM multisatellite precipitation analysis (tmpa): quasi-global, multiyear, combined-sensor precipitation estimates at fine scales. Journal of Hydrometeorology, 8, 38-55. doi: 10.1175/JHM560.1

Hydrologic Modeling System HEC-HMS. (2016). User's Manual, Version 4.2, US Army Corps of Engineers, Hydrologic Engineering Center: Davis, CA, USA.

Institute of Geology and Mineral Exploitation - IGME (1993), Engineering geological map of Greece, scale 1:500000. Greece, Athens 1993.

Joyce R.J., Janowiak J.E., Arkin P.A. and Xie P. (2004), CMORPH: A method that produces global precipitation estimates from pas-sive microwave and infrared data at high spatial and temporal resolution. Journal of Hydrometeorology, 5, 487-503. doi: 10.1175/15257541(2004)005<0487:CAMTPG>2.0.CO,2.

Karagiannidis A., Lagouvardos K., Kotroni V. and Giannaros T.M. (2021), Assessment of the v2016 NWCSAF CRR and CRR-Ph precipitation estimation performance over the Greek area using rain gauge data as ground truth. Meteorology and Atmospheric Physics, 133, 879-890. https://doi.org/10.1007/s00703-021-00783-4.

Kastridis A. and Stathis D. (2015). The effect of small earth dams and reservoirs efficiency in water management in North Greece (Kerkini Municipality). Silva Balcanica, 16(2), 71-84.

https://silvabalcanica.files.wordpress.com/2015/09/sb_1622015- 071-084.pdf

Kastridis A. and Stathis D. (2020). Evaluation of hydrological and hydraulic models applied in typical mediterranean ungauged watersheds using post-flash-flood measurements. Hydrology, 7, 12. https://doi.org/10.3390/hydrology7010012.

Kastridis A., Kirkenidis C. and Sapountzis M. (2020). An integrated approach of flash flood analysis in ungauged Mediterranean watersheds using post-flood surveys and unmanned aerial vehicles. Hydrological Processes, 34: 4920-4939. https://doi.org/10.1002/hyp.13913.

Katsanos D., Lagouvardos K., Kotroni V. and Huffmann G. (2004). Statistical evaluation of MPA-RT high-resolution precipitation estimates from satellite platforms over the Central and Eastern Mediterranean. Geophysical Research Letters, 31, art. no. L06116.

Kazamias A.P., Sapountzis M. and Lagouvardos K. (2017). Evaluation and intercomparison of GPM-IMERG and TRMM 3B42 daily precipitation products over Greece", Proc. SPIE 10444, Fifth International Conference on Remote Sensing and Geoinformation of the Environment (RSCy2017), $1044413 \quad$ (6 September 2017), https://doi.org/10.1117/12.2279689.

Kelsch M., Caporali E. and Lanza L.G. (2001). Hydrometeorology of Flash Floods. In: Gruntfest E., Handmer J. (eds) Coping With Flash Floods. NATO Science Series (Series 2. Environmental Security), vol $77 . \quad$ Springer, Dordrecht. https://doi.org/10.1007/978-94-010-0918-8_4.
Koenig T.A., Bruce J.L., O'Connor J.E., McGee B.D., Holmes R.R., Jr., Hollins R., Forbes B.T., Kohn M.S., Schellekens M., Martin Z.W., et al. (2016). Identifying and preserving high-water mark data. U.S. Geol. Surv. Chapter 24, Tech. Methods 3-A24, 3, 47.

Kotroni V., Lagouvardos K., Defer E., Dietrich S., Porcù F., Medaglia C.M. and Demirtas M. (2005). The Antalya 5 December 2002 storm: Observations and model analysis. Journal of Applied Meteorology,

45,

576-590. https://doi.org/10.1175/JAM2347.1.

Lagouvardos K., Dafis S., Giannaros C., Karagiannidis A. and Kotroni V. (2020). Investigating the role of extreme synoptic patterns and complex topography during two heavy rainfall events in crete in February 2019. Climate, 8, 87. https://doi.org/10.3390/cli8070087.

Lagouvardos K., Kotroni V., Bezes A., Koletsis I., Kopania T., Lykoudis S., ... and Vougioukas S. (2017). The automatic weather stations NOANN network of the National Observatory of Athens: Operation and database. Geoscience Data Journal, 4(1), 4-16. https://doi.org/10.1002/gdj3.44.

Liu J., Du J., Yang Y. and Wang Y. (2020). Evaluating extreme precipitation estimations based on the GPM IMERG products over the Yangtze River Basin, China, Geomatics, Natural Hazards and Risk, 11:1, 601-618. doi: 10.1080/19475705.2020.1734103.

Ma Q., Li Y., Feng H., Yu Q., Zou Y., Liu F. and Pulatov B. (2021). Performance evaluation and correction of precipitation data using the 20-year IMERG and TMPA precipitation products in diverse subregions of China. Atmospheric Research 249, 105304, https://doi.org/10.1016/j.atmosres.2020.105304.

Maghsood F.F., Hashemi H., Hosseini S.H. and Berndtsson R. (2020). Ground validation of GPM IMERG precipitation products over Iran. Remote Sensing, 12:1-23. doi: 10.3390/RS12010048.

Manning R. (1891). On the flow of water in open channels and pipes. Transactions of the Inst. Civil Engineers of Ireland, 20, 161-207.

Manz B., Páez-Bimos S., Horna N., Buytaert W., Ochoa-Tocachi B., Lavado-Casimiro W. and Willems B. (2017). Comparative ground validation of IMERG and TMPA at variable spatiotemporal scales in the tropical andes. Journal of Hydrometeorology, 18, 2469-2489. doi: 10.1175/JHM-D-16-0277.1

Marchi L., Borga M., Preciso E. and Gaume E. (2010). Characterization of selected extreme flash floods in Europe and implications for flood risk management. Journal of Hydrology, 394(1-2), 118-133. https://doi.org/10.1016/ j.jhydrol.2010.07.017.

Marchi L., Borga M., Preciso E., Sangati M., Gaume E., Bain V. and Pogacnik N. (2009). Comprehensive post-event survey of a flash flood in Western Slovenia: Observation strategy and lessons learned. Hydrological Processes, 23(26), 3761-3770.

Marcos C., Sancho J.M. and Tapiador F.J. (2015), NWC SAF convective precipitation product from MSG: a new day-time method based on cloud top physical properties. Thethys Journal of Mediterranean Meteorology and Climatology, 12, 3-11. https ://doi.org/10.3369/tethy s.2015.12.01

Michailidi E.A., Antoniadi S., Koukouvinos A., Bacchi B. and Efstratiadis A. (2018). Timing the time of concentration: Shedding light on a paradox. Hydrological Sciences Journal, 63(5),721-740. https://doi.org/10.1080/02626667.2018. 1450985 . 
Moriasi D., Arnold J., Van Liew M., Bingner R., Harmel R. and Veith T. (2007). Model evaluation guidelines for systematic quantification of accuracy in watershed simulations. Transactions of the ASABE, 50(3), 885-900. https://doi.org/ 10.13031/2013.23153.

Nash J. and Sutcliffe J.V. (1970). River flow forecasting through conceptual models part I-A discussion of principles. Journal of Hydrology, 10(3), 282-290. https://doi.org/10.1016/00221694(70)90255-6.

Rezaei-Sadr H. (2017). Influence of coarse soils with high hydraulic conductivity on the applicability of the SCSCN method. Hydrological Sciences Journal, 62, 843-848. doi:10.1080/02626667.2016.1262037.

Sapountzis M. and Stathis D. (2014). Relationship between Rainfall and Run-off in the Stratoni Region (N. Greece) after the storm of $10^{\text {th }}$ February 2010. Global Nest Journal, 2014, 16, 420-431. https://doi.org/10.30955/gnj.001234.

Singh J., Knapp H.V., Arnold J. and Demissie M. (2005). Hydrological modeling of the iroquois river watershed using hspf and swat1. Journal of the American Water Resources Association, 41, 343-360. https://doi.org/10.1111/j.17521688.2005.tb03740.x.

Soil Conservation Service - SCS (1972). National Engineering Handbook, Section 4: Hydrology. Department of Agriculture, Washington DC, $762 \mathrm{p}$.

Soo E.Z.X., Jaafar W.Z.W., Lai S.H., et al. (2020), Precision of raw and bias-adjusted satellite precipitation estimations (Trmm, imerg, cmorph, and persiann) over extreme flood events: Case study in langat river basin, Malaysia. Journal of Water and Climate Change, 11, 322-342. doi: 10.2166/wcc.2020. 180.

Soulis K. (2018), Estimation of SCS Curve Number variation following forest fires. Hydrological Sciences Journal, 63, 13321346. doi:10.1080/02626667.2018.1501482.

Stathis D., Sapountzis M. and Myronidis D. (2010), Assessment of land use change effect on design storm hydrograph using the SCS curve number method. Fresenius Environmental Bulletin, 19, 1928-1934.

Sun Q., Miao C., Duan Q., Ashouri H., Sorooshian S. and Hsu K.L. (2018). A review of global precipitation data sets: data sources, estimation, and intercomparisons. Reviews of Geophysics, 56, 79-107. https://doi.org/10.1002/2017RG 000574.

Tzioutzios C. and Kastridis A. (2020). Multi-Criteria Evaluation (MCE) Method for the management of woodland plantations in floodplain areas. ISPRS International Journal of Geo-Information, 9(12), 725. https://doi.org/10.3390/ijgi9120725.

United States Department of Agriculture - USDA (2010). Time of Concentration. In L. Owens (Ed.), Part 630 Hydrology, National Engineering Handbook (Ch. 15). Washington, DC: Natural Resources, Conservation Service, Conservation Engi-neering Division.

Van Liew M.W., Arnold J.G. and Garbrecht J.D. (2003). Hydrologic simulation on agricultural watersheds: Choosing between two models. Transactions of the American Society of Agricultural Engineers, 46(6), 1539-1551.

Varlas G., Anagnostou M.N., Spyrou C., Papadopoulos A., Kalogiros J., Mentzafou A., Michaelides S., Baltas E., Karymbalis E. and Katsafados P. (2019). A Multi-Platform Hydrometeorological Analysis of the Flash Flood Event of 15
November 2017 in Attica, Greece. Remote Sensing, 11, 45. https://doi.org/10.3390/rs11010045.

Verma S., Verma R.K., Mishra S.K., Singh A. and Jayaraj G.K. (2017). A revisit of NRCS-CN inspired models coupled with RS and GIS for runoff estimation. Hydrological Sciences Journal, 62, 1891-1930. doi:10.1080/02626667.2017.1334166.

Xu S., Shen Y. and Niu Z. (2019). Evaluation of the IMERG version 05B precipitation product and comparison with IMERG version 04A over mainland China at hourly and daily scales. Advances in Space Research, 63:2387-2398. doi: 10.1016/j.asr.2019.01.014. 